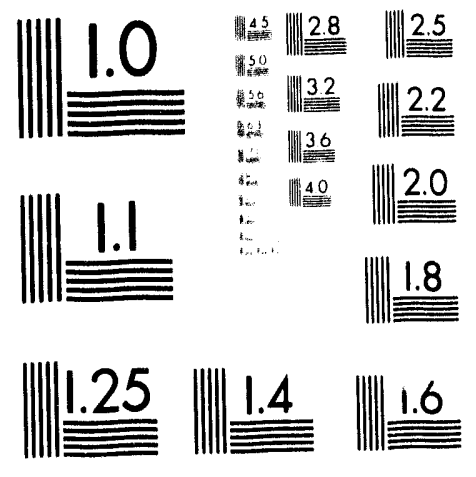



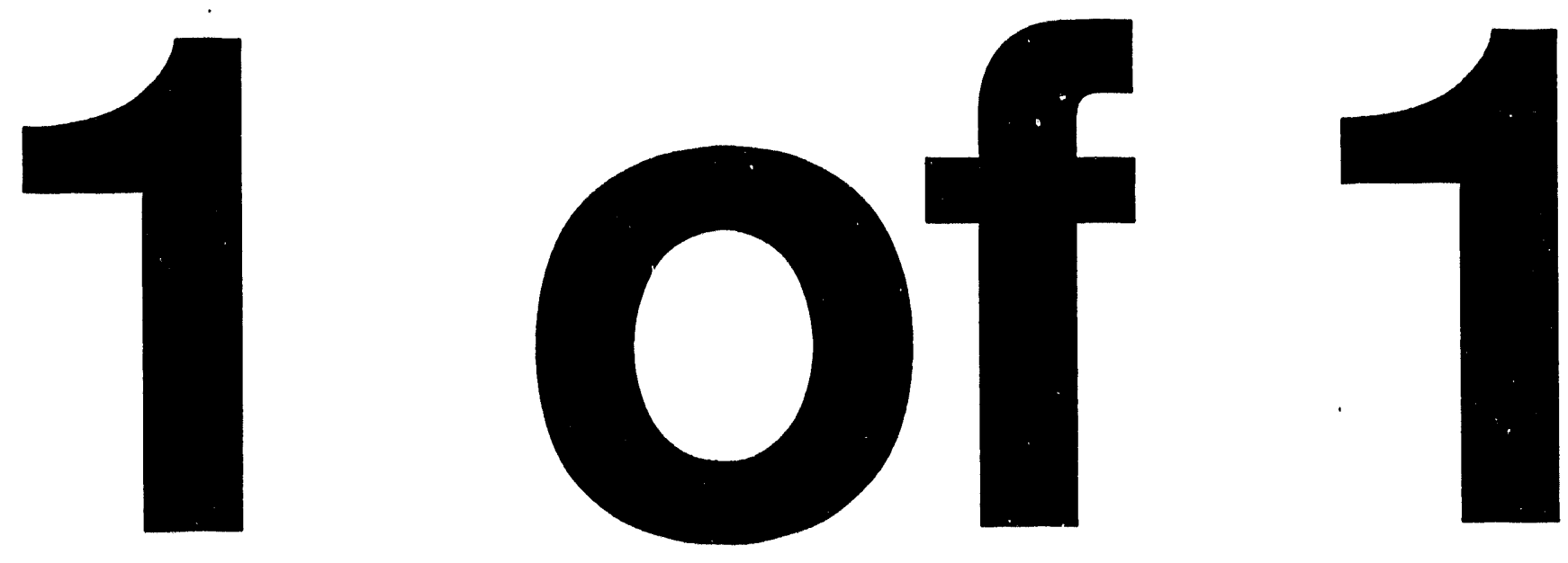


\title{
Interim Criteria For Organic Watch List Tanks at the Hanford Site
}

\author{
H. Babad \\ D. A. Turner
}

Date Published

September 1993

Prepared for the U.S. Department of Energy Office of Environmental Restoration and Waste Management

$\begin{array}{ll}\text { Westinghouse } & \text { P.O Box } 1970 \\ \text { Hanford Company } & \text { Richland. Washington } 39352\end{array}$

Hantord Operations and Engineering Contractor tor the

US Department of Energy under Contract DE ACO6 87RL 10930 
WHC-EP-.0681

\section{APPROVAL PAGE}

Document Title:

Approved by:

Approved by:

Approved by:

Approved by:

Interim Criteria for Organic Watch List Tanks ar the Hanford Site

$D$ atwer

D. A. Turner, Manager

Waste Tank Organic Safety Program
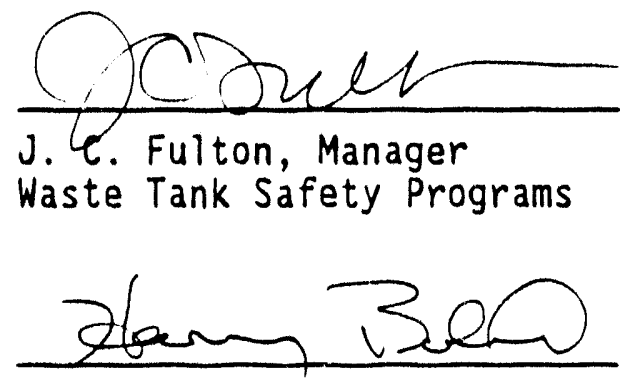

H. Babad, Advisory Chemist Waste Tank Safety Programs

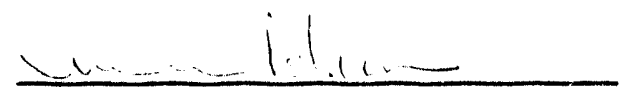

M. N. Islam, Manager Waste Tank Safety Assurance

$\frac{9-28-93}{\text { Date }}$

$9-28-93$ Date

$9-28 \cdot 93$ Date

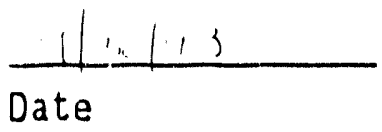




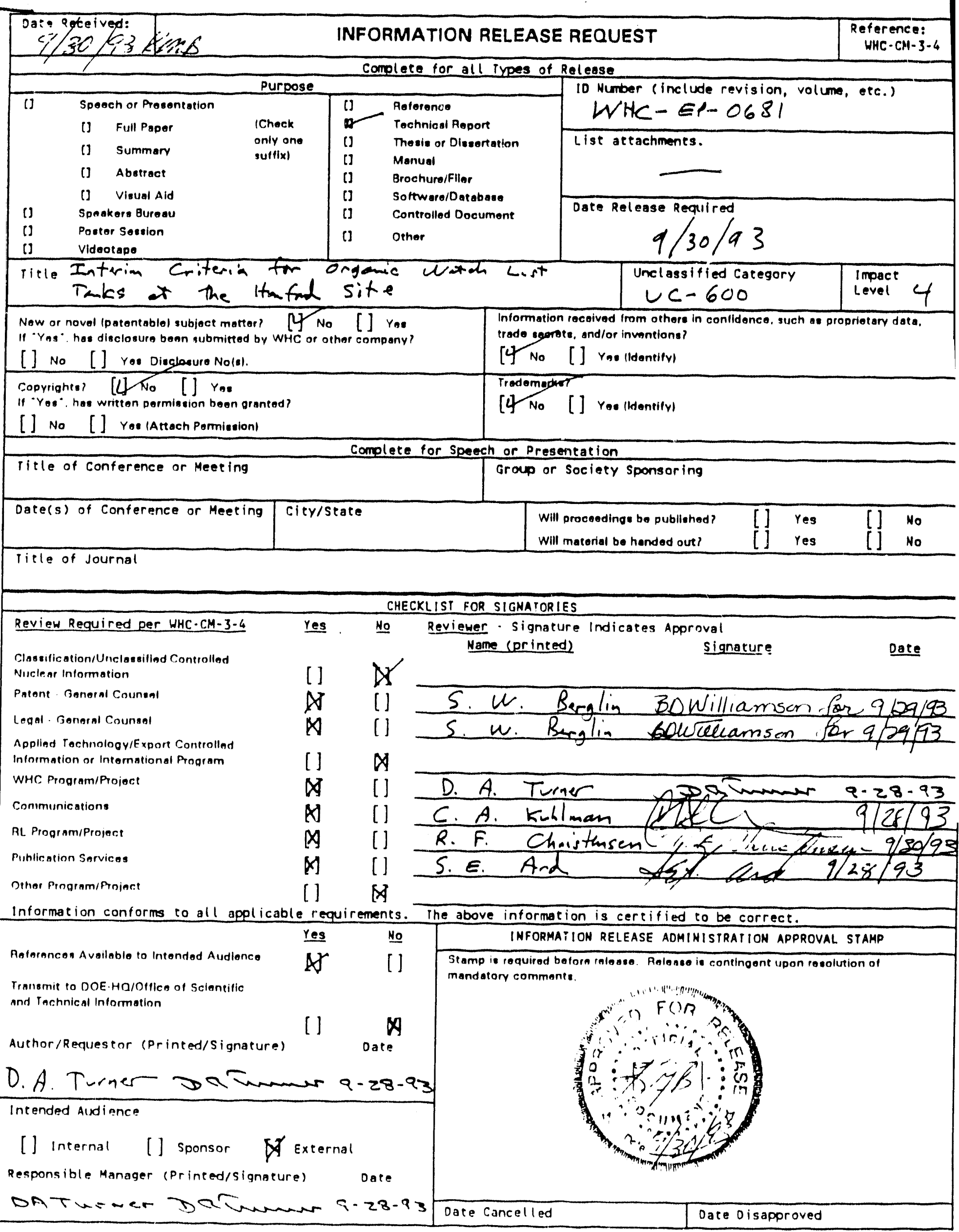




\section{CONTENTS}

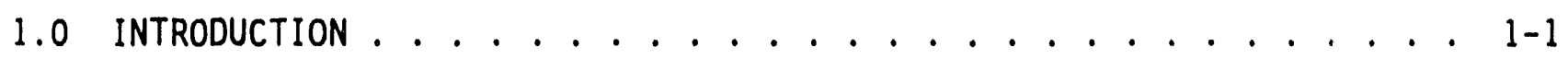

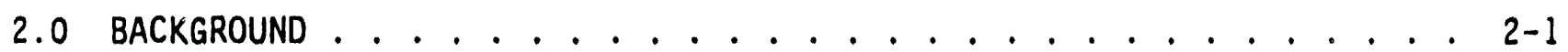

3.0 STRATEGY FOR SAFETY ISSUE RESOLUTION . . . . . . . . . 3-1

4.0 INTERIM CRITERIA FOR ORGANIC WATCH LIST

TANKS AT THE HANFORD SITE ................ . 4-1

5.0 TECHNICAL BASIS . . . . . . . . . . . . . 5-1

5.1 REPRESENTATIVE ORGANIC WASTE SURROGATE . . . . . . . 5-1

5.2 LEVEL 1 CRITERIA . . . . . . . . . . . . . . . . . . 5-3

5.3 LEVEL 2 CRITERIA . . . . . . . . . . . . . . . 5-5

5.4 LEVEL 3 CRITERIA ................. . . 5-7

6.0 TECHIICAL CONSERVATISM ................. 6-1

6.1 REPRESENTATIVE ORGANIC WASTE SURROGATE . . . . . . . . . 6-1

6.2 WASTE TEMPERATURE . . . . . . . . . . . . . . . . 6-2

6.3 WASTE ORGANIC CONCENTRATION ............... . . 6-2

6.4 WASTE MOISTURE CONTENT . . . . . . . . . . . . . . . . . . . 6-3

7.0 REFERENCES .................. . . . . . APPENDIXES

A SAFETY OBJECTIVE ............................. App A-1

B ORGANIC WASTE SURROGATE ................ App B-1

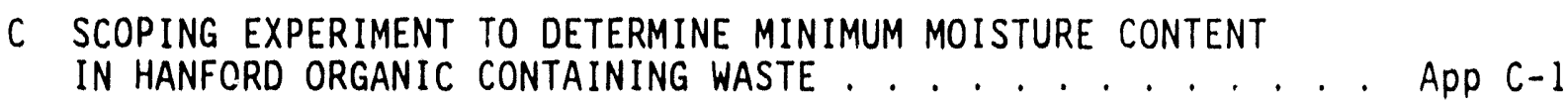


WHC-EP-0681

LIST OF FIGURES

3-1 Strategy for Organic Tanks Safety Issue Resolution........ 3-3

\section{LIST OF TABLES}

2-1 Organic Tanks Watch List - September $1993 \ldots \ldots$ 2-1

3-1 Relationship Between Waste Classification Level and Organic Tanks Watch List ............... . 3-2

4-1 Interim Criteria for Organic Watch List Tanks at the Hanford Site ....... . . . . . . . . . . . . . . 4-1

5-1 Organic Chemicals Disposed to Underground Storage Tanks ...... 5-1

5-2 Test Mixtures for Fauske \& Associates, Inc.

RSST Adiabatic Calorimeter Tests . . . . . . . . . . . . . 5-3

5-3 RSST Gas Pressures After Cooldown . . . . . . . . . . . . . . 5-4

5-4 DSC Results for Sodium Salt of Ethylenediaminetetracetic Acid (Without Oxidizer) in Flowing Air and Nitrogen . . . . . . . . . . . 5-5

6-1 Carbon to Hydrogen Ratio ................. 6-1

6-2 Stoichiometric Reactant Quantities............... 6-3

6-3 Inorganic Constituents of Hanford Waste . . . . . . . . . . . . 6-4 


\section{ACRONYMS}

DSC

EDTA

FY

$\mathrm{g}$

$\mathrm{kg}$

MJ

psi

RSST

TOC

TRAC

VSP
Differential Scanning Calorimeter sodium salt of ethylenediaminetetraacetic acid Fiscal Year

grams

Joules

kilograms

mega Joules

pounds per square inch

Reactive System Screening Tool

total organic carbon

Tracks Radioactive Components (computer code)

Vent Sizing Package 
WHC-EP-0681

This page intentionally left blank. 


\subsection{INTRODUCTION}

This document establishes interim criteria for identifying single-shell radioactive waste storage tanks at the Hanford Site that contain organic chemicals mixed with nitrate/nitrite salts in potentially hazardous concentrations. These tanks are designated as "organic Watch List tanks."

Watch List tanks are radioactive waste storage tanks that have the potential for release of high-level waste as a result of uncontrolled increases in temperature or pressure. Organic Watch List tanks are those Watch List tanks that contain relatively high concentrations of organic chemicals.

Because of the potential for release of high-level waste resulting from uncontrolled increases tn temperature or pressure, the organic Watch List tanks (collectively) constitute a Hanford Site radioactive waste storage tank "safety issue."

The approach established for identifying single-shell waste tanks to be included on the organic tanks watch List requires that the waste in each tank be classified as safe, conditionally safe, or unsafe. The interim criteria presented in this document will be used to achieve this classification on a preliminary basis.

Single-shell tanks with waste classified as "safe" will not be included on the organic tanks Watch List. Routine tank monitoring will continue.

Single-shell tanks with waste classified as "conditionally safe" will be included on the organic tanks Watch List. Enhanced tank monitoring will be initiated.

Single-shell tanks with waste classified as "unsafe" will be included on the organic tanks Watch List. Enhanced tank monitoring will be initiated. A tank with waste classified as "unsafe" will be subject to near-term mitigation and/or remediation actions. The programmatic logic for these actions is described in Status Report on Resolution of the Waste Tank Safety Issues at the Hanford Site (Reep 1993). reasons.

The criteria are designated as "interim criteria" for the following

- The technical information supporting the criteria is preliminary in nature and of limited availability at this time. Additional technical information is required to verify the technical basis for the criteria.

- The criteria are subject to revision based on new technical information. 
WHC-EP-0681

- The criteria are to be used to conduct a preliminary screening of the 149 single-shell waste tanks at the Hanford Site to identify candidates for the organic tanks Watch List. The purpose here in is to identify tanks that require enhanced levels of monitoring and controls to meet safe interim storage objectives.

- The criteria are not intended to be used, in their present state of development, for resolution of the organic tanks safety issue. Additional laboratory testing, waste characterization data, and technical analyses are required to support safety issue resolution in a satisfactory manner. 


\subsection{BACKGROUND}

Nine single-shell radioactive waste storage tanks are currently included on the organic tanks Watch List. These nine tanks are identified in Table 2-1. Eight of the tanks are included on the Watch List based on inferred total organic carbon (TOC) content $>3$ wt.\% (dry basis). A ninth tank (241-C-103) is included because it has a floating organic layer. An Unreviewed Safety question was al so declared for tank 241-C-103 on September 21, 1992 because the potential for ignition and combustion of the floating organic layer is not adequately addressed by existing safety documentation (Richardson 1992).

Table 2-1. Organic Tanks Watch List September 1993.

\begin{tabular}{|c|c|}
\hline Single-She11 Waste Tank & $\begin{array}{c}\text { Organic Content wt.\% } \\
\text { TOC (dry basis) }\end{array}$ \\
\hline $241-B-103$ & 3.3 \\
\hline $241-C-103$ & -- \\
\hline $241-S-102$ & 6.1 \\
\hline $241-S X-106$ & 4.3 \\
\hline $241-T X-105$ & 3.7 \\
\hline $241-T X-118$ & 5.9 \\
\hline $241-U-106$ & 13.6 \\
\hline $241-U-107$ & 4.3 \\
\hline $241-U-111$ & $\sim 14$ \\
\hline
\end{tabular}

'Tank $241-c-103$ is included on the organic tanks Watch List because the potential for ignition and combustion of the floating organic layer is not adequately addressed by existing safety documentation.

The technical basis for the current organic Watch List tank criterion [TOC >3 wt.\% (dry basis)], is described in The Kyshtym Explosion and Explosion Hazards with Nitrate-Nitrite Bearing Waste with Acetates and other Organic Salts (Fisher 1990). 
The following technical deficiencies of the current organic tanks Watch List criterion are recognized.

- The TOC $>3$ wt.\% (dry basis) criterion is based on limited iaboratory screening studies (Fisher 1990). These screening studies are, at best, qualitative in nature, and would be difficult to validate.

- The criterion does not address waste moisture content, which reduces the potential for a propagating organic-nitrate/ nitrite reaction.

- The criterion does not address waste temperature, a key parameter controlling the potential for a propagating organic-nitrate/nitrite reaction.

Accordingly, the criteria presented in this document have been developed with the objective of redressing these technical deficiencies.

The Hanford Site Tank Farms Facilities Interim Safety Basis (WHC 1993) addresses the organic tanks safety issue in the following four categories:

- Potential uncontrolled reactions between air and flammable gases (radiolytics, volatiles, and aerosols) in the tanks' headspace

- Potential uncontrolled reactions between a flammable liquid and air (a pool fire) in tanks that have floating organic layer (tank 241-C-103)

- Potential uncontrolled reactions between air and solid waste saturated with organic liquid at the air/waste interface

- Potential uncontrolled reactions between organic chemicals (fuel) and nitrate/nitrite salts (oxidizer) in solid waste.

This document addresses the fourth organic tanks safety issue category, potential uncontrolled reactions between organic chemicals and nitrate/nitrite salts.

Criteria that address the remaining three organic tanks safety issue categories will be developed as the Waste Tank Organic Safety Program matures. Additional information is required to develop technically based criteria for these remaining three categories. Rationale is outlined below:

- Instrumentation to representatively sample flammable gases (radiolytics, volatiles, and aerosols) in a tank's headspace has not been deployed in the organic Watch List tanks. This task is scheduled to be accomplished in the fiscal year (FY) 1994-1996 timeframe. Operating specifications for organic Watch List tanks (Godfrey 1992) currently require that flammable gas concentrations 'n a tank's headspace be less than 20 percent of the lower fi immability limit before conducting any work inside the primary 
ventilation space (tank's headspace or associated exhaust ventilation system)*. The safety issue relates to the ability to representatively sample radiolytic, volatile, and aerosol constituents in the tank's headspace. Heated tube sampling systems are planned to provide representative sampling capability.

- The floating organic layer in tank $241-C-103$ has not been adequately characterized to permit assessment of the safety issue. Some evidence suggests that the floating organic: layer in this tank might be made inert by dissolved water (WHC 1993). Near-term plans include the retrieval of dip samples of the floating organic layer and underlying aqueous phase, their analysis, and completion of a safety assessment based on the analytical results. This is scheduled to be followed by removal of the floating organic layer from the tank during FY 1995.

- No single-shell waste tanks are currently included on the organic tanks Watch List because of the potential for an uncontrolled reaction between air and solid waste saturated with organic liquid at the air/waste interface. However, the need for an Unreviewed Safety Question screening for tank 241-C-102, and possibly other tanks, is being investigated. Tanks 241-C-102, 241-C-104, and 241-BY-112 contained floating organic layers at one time. The safety concern is related to whether organic liquid could have been absorbed in solids at the waste surface during operations to remove supernatant and drainable interstitial liquids from the tanks. blank.

*The National Fire Protection Association recommends 25 percent of the lower flammability limit. Operating specifications are currently established (conservatively) below this value. 
WHC-EP-0681

This page intentionally left blank. 


\subsection{STRATEGY FOR SAFETY ISSUE RESOLUTION}

The strategy to be employed for organic tanks safety issue resolution (Christensen 1993) is shown in Figure 3-1. This strategy was transmitted to the Defense Nuclear Facilities Safety Board by the U.S. Department of Energy, Headquarters on August 25, 1993 (Christensen 1993). The following are key steps leading toward safety issue resolution:

- Identification of criteria for organic tanks safety issue resolution

- Classification of waste in single-shell tanks into three levels (safe, conditionally safe, and unsafe), in compliance with the criteria.

This document represents a first step toward identification of criteria for organic tanks safety issue resolution. However, as stated in Section 1.0, the interim criteria are not intended to be used in their present state of development for resolution of the organic tanks safety issue. Rather, the interim criteria are intended to be used to conduct a preliminary screening of the 149 single-shell waste tanks at the Hanford Site to identify candidates for the organic tanks Watch List.

Preliminary classification of waste in single-shell tanks into three safety levels (safe, conditionally safe, and unsafe), in compliance with the interim criteria, will be accomplished by the Waste Tank Organic Safety Program during FY 1994 and reported in separate documentation.

The relationship between classification of waste into three safety levels (safe, conditionally safe, and unsafe), and identification of single-shell waste tanks to be included on the organic tanks Watch List is shown in Table 3-1.

Single-shell tanks with waste classified as "safe" will not be included on the organic tanks Watch List. Routine tank monitoring will continue.

Single-shell tanks with waste classified as "conditionally safe" will be included on the organic tanks Watch List. Tank monitoring will be initiated in compliance with operating specifications for Watch List tanks (Godfrey 1992). Technical activities supporting resolution of the organic tanks safety issue will continue.

Single-shell tanks with waste classified as "unsafe" will be included on the organic tanks Watch List. Tank monitoring will be initiated in compliance with operating specifications for Watch List tanks (Godfrey 1992). Near-term safety issue mitigation and/or remediation actions will be implemented as is technically feasible. "Mitigation" implies in-tank waste treatment to convert single-shell tank waste classified as "unsafe" to a "conditionally safe" classification. Mitigation actions might include adding water to a singleshell tank to increase waste moisture content, or adding water to and force ventilating a tank to reduce waste temperature. "Remediation" implies waste retrieval and out-of-tank treatment to achieve safety issue resolution. 
The following waste parameters are to be addressed in the interim criteria:

- Waste organic concentration

- Waste moisture content

- Waste temperature.

The single-shell tank safety objective that leads to classification of waste into three safety levels is discussed in detafl in Appendix $A$.

Table 3-1. Relationship Between Waste Classification Level and Organic Tanks Watch List.

\begin{tabular}{|c|c|c|}
\hline $\begin{array}{c}\text { Waste Classification } \\
\text { Level }\end{array}$ & $\begin{array}{l}\text { Include Tank On } \\
\text { Organic Tanks } \\
\text { Watch List }\end{array}$ & $\begin{array}{c}\text { Safety Issue Management } \\
\text { Response }\end{array}$ \\
\hline Safe & No & $\begin{array}{l}\text { Continue routine tank } \\
\text { monitoring. }\end{array}$ \\
\hline Conditionally safe & Yes & $\begin{array}{l}\text { Initiate tank monitoring in } \\
\text { compliance with operating } \\
\text { specifications for Watch List } \\
\text { tanks. }\end{array}$ \\
\hline Unsafe & Yes & $\begin{array}{l}\text { Initiate tank monitoring in } \\
\text { compliance with operating } \\
\text { specifications for watch List } \\
\text { tanks. } \\
\text { Implement near-term safety } \\
\text { issue mitigation and/or } \\
\text { remediation actions as } \\
\text { technically feasible. }\end{array}$ \\
\hline
\end{tabular}


Figure 3-1. Strategy for Organtc Tanks Safety Issue Resolution.

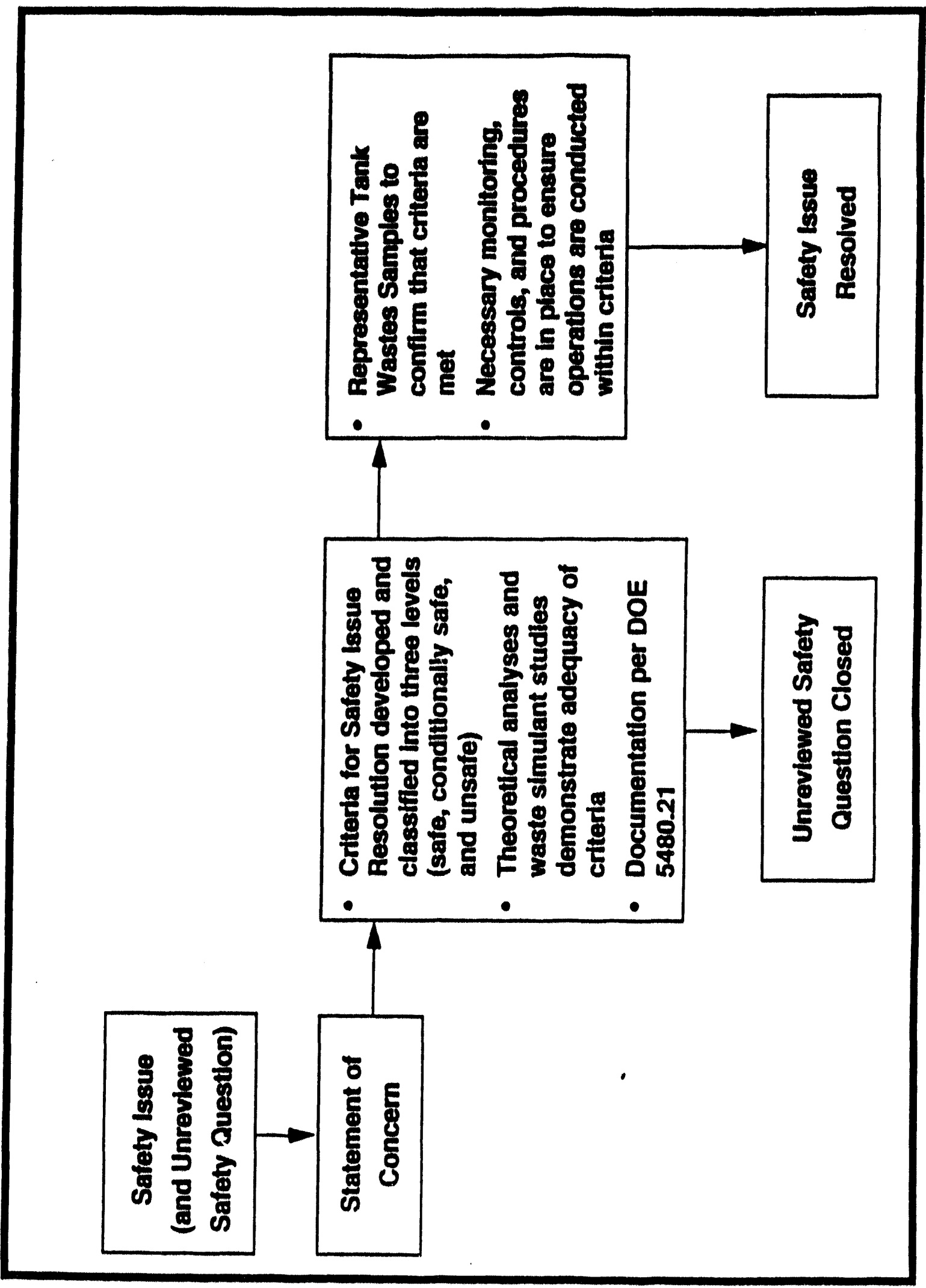


WHC-EP-0681

This page intentionally left blank. 


\subsection{INTERIM CRITERIA FOR ORGANIC WATCH LIST TANKS AT THE HANFORD SITE}

Interim criteria for organic Watch List tanks at the Hanford Site are summarized in Table 4-1.

As indicated in Section 3.0, "Strategy for Safety Issue Resolution," waste in single-shell tanks will be classified into three levels (safe, conditionally safe, and unsafe). Single-shell tanks with waste classified as "safe" will not be included on the organic tanks Watch List. Tank with waste classifled as "conditionally safe" or "unsafe" will be included on the organic tanks Watch List.

Criteria for classifying single-shell tank waste as safe, conditionally safe, or unsafe (and thereby identifying single-shell tanks to be included on the organic tanks Watch List in compliance with Table 4-1), are discussed in this section. The technical basis supporting the criteria is addressed in Section 5.0. Technical conservatism is addressed in Section 6.0.

Table 4-1. Interim Criteria for Organic Watch List Tanks at the Hanford Site.

\begin{tabular}{|c|c|c|c|}
\hline \multirow{2}{*}{ Level } & \multirow{2}{*}{$\begin{array}{c}\text { Waste } \\
\text { classification }\end{array}$} & \multicolumn{2}{|l|}{ Criteria } \\
\hline & & Parameter & Value \\
\hline 1 & Safe & $\begin{array}{l}\text { Waste organic concentration } \\
\text { Waste temperature }\end{array}$ & $\begin{array}{l}\leq 5 w t . \% \text { TOC (dry } \\
\text { basis), and } \\
<149{ }^{\circ} \mathrm{C}\end{array}$ \\
\hline 2 & $\begin{array}{l}\text { Conditionally } \\
\text { safe }\end{array}$ & $\begin{array}{l}\text { Waste organic concentration } \\
\text { Waste moisture content } \\
\text { Waste temperature }\end{array}$ & $\begin{array}{l}>5 \text { wt. } \% \text { TOC (dry } \\
\text { basis), and } \\
\geq 17 \mathrm{wt} . \% \text {, and } \\
\leq 90^{\circ} \mathrm{C}\end{array}$ \\
\hline 3 & Unsafe & \multicolumn{2}{|c|}{ Failure to meet Level 2 Criteria } \\
\hline
\end{tabular}


Level 1 - Safe (Non-Watch List Tank)--Single-shell tank waste will be classified as "safe" if the following criterta are met:

- The TOC content of the waste is $\leq 5 w t . \% *$ (dry basis), and

- Waste temparature is $<149^{\circ} \mathrm{C} \star *$.

Nitrate/nitrite concentration and waste moisture content are not 1 imiting (constraining) parameters (Christensen 1993).

Level 2 - Conditionally Safe (Watch List Tank)--Single-shell tank waste will be classified as "conditionally safe" if the following criteria are met:

- The TOC content of the waste is $>5$ wt.\% (dry basis), and

*This criterion implies the following:

- The TOC content of the waste has, at no point within the tank, been measured (based on waste sample analytical data) to exceed 5 wt.\% (dry basis), or

- The average TOC content of the waste, inferred from the TRAC computer code (Jungfleisch 1984), does not exceed $x$ wt.\% (dry basis). The value of $x$ will be determined by work currently in progress by the Waste Tank Organic Safety Program to "calibrate" the TRAC computer code using waste sample analytical data.

- The TOC content of the waste will be determined from waste sample analytical data, rather than the TRAC computer code, if waste sample analytical data is available.

**Based on temperature measurements using instrumentation available within single-shell waste tanks as of December 31, 1993. 
- Waste molsture content is $217 w t . \%, *$ and

- Waste temperature is $590^{\circ} \mathrm{C} * \star$.

Nitrate/nitrite concentration is not a 1 imiting (constraining) parameter (DOE 1993).

Level 3 - Unsafe (Watch List Tank Subject to Near-Term Mitigation/ Remediation Actions)--Single-shell tank waste will be classified as "unsafe" if the waste falls to meet the Level 2 Criteria (Christensen 1993).

*This criterion implies the following:

- The moisture content of the waste has, at no point within the tank, been measured (based on waste sample analytical data) to be less than $17 w t . \%$, and

- Compliance with the criterion may be inferred from the presence of free standing liquid on the waste surface. "Waste surface" is defined as a continuous layer of solids that span the diameter of the tank, not as waste solids that might be present on the surface of free standing liquid because of buoyant forces, or

- Compliance with the criterion may be inferred from appropriate laboratory analytical data on representative single-shell tank waste simulants. The laboratory analytical data must confirm that the equilibrium molsture content of single-shell tank waste, from which water is free to evaporate under representative single-shell tank waste storage conditions (including active ventilation), exceeds 17 wt.\%. Appendix $C$ illustrates preliminary laboratory analytical data obtained to investigate this method uf demonstrating compliance with the waste moisture criterion.

**Based on temperature measurements using instrumentation available within single-shell waste tanks as of December 31, 1993. 
WHC-EP-0681

This page intentionally left blank.

$4-4$ 
WHC-EP-0681

\subsection{TECHMICAL BASIS}

The technical basis supporting the interim organic Watch List tank criterta is presented in the following sections.

\subsection{REPRESENTATIVE ORGANIC WASTE SURROGATE}

Large quantities of organic chemicals have been disposed to single-shell tanks at the Hanford Site as waste from chemical processing operations (Allen 1976, Martin 1985, Gerber, et. a1. 1992). "Estimated Inventory of Chemicals Added to Underground Waste Tanks, 1944 through 1975" (Allen 1976) suggests that the majority of the disposed organtcs are those shown in Table 5-1.

Table 5-1. Organic Chemicals Disposed to Underground Storage Tanks.

\begin{tabular}{|l|c|c|}
\hline \multicolumn{1}{|c|}{ Organic Chemical } & Formula for Sodium Salt & Quantity (Gram Moles) \\
\hline Hydroxyacetic Acid & $\mathrm{NaC}_{2} \mathrm{H}_{3} \mathrm{O}_{3}$ & $9.0 \times 10^{6}$ \\
\hline Citric Acid $^{\prime}$ & $\mathrm{Na}_{3} \mathrm{C}_{6} \mathrm{H}_{3} \mathrm{O}_{7}$ & $3.3 \times 10^{6}$ \\
\hline HEDTA $^{1}$ & $\mathrm{Na}_{3} \mathrm{C}_{10} \mathrm{H}_{15} \mathrm{O}_{7} \mathrm{~N}_{2}$ & $2.7 \times 10^{6}$ \\
\hline EDTA $^{2}$ & $\mathrm{Na}_{4} \mathrm{C}_{10} \mathrm{H}_{12} \mathrm{O}_{8} \mathrm{~N}_{2}$ & $0.57 \times 10^{6}$ \\
\hline
\end{tabular}

${ }^{1} \mathrm{~N}$-(hydroxyethyl)-ethylenediaminetriacetic acid

'Ethylenediaminetetraacetic acid

${ }^{3}$ Form of compound existing in strongly alkaline environment of single-shell tank waste

The information in Table 5-1 was derived from process flowsheet compositions and recorded waste volumes sent to underground waste storage tanks from 1944 through 1975 (Allen 1976).

In Appendix $\mathrm{B}$, it is demonstrated that sodium acetate $\left(\mathrm{NaC}_{2} \mathrm{H}_{3} \mathrm{O}_{2}\right)$ closely approximates the "weighted average" chemical formula of the organic chemicals shown in Table 5-1. For this reason, sodium acetate is proposed to be a representative organic waste surrogate for estimating the energetics of single-shell tank waste relative to a propagating organic-nitrate/nitrite reaction.

The use of sodium acetate as a representative organic waste surrogate needs to be qualified in three respects:

- It does not account for the presence of process solvents (principally normal paraffin hydrocarbons and tributyl phosphate and their degradation products) that were originally present in unknown (but possibly significant) quantities in the single-shell waste tanks. Although process solvents were not routinely disposed in the single-shell tank system as such (i.e., as reflected in process flowsheet compositions and recorded waste volumes), significant 
quantities entered the tanks entrained in "organic wash waste" from the chemical process facllities. The fate of process solvents disposed in the single-shell waste tanks is largely unknown. A major fraction of the organic originally present might have been lost over the course of time as a result of evaporation and waste evaporator operations (e.g., normal paraffin hydrocarbons), or hydrolyzed to a less reactive waste form (e.g., tributyl phosphate). "Resolving the Safety Issue for Radioactive Waste Tanks with High Organic Content" (Babad et. al. 1993a) indicates, based on thermodynamic considerations, that the energetics of an organicnitrate/nitrite reaction involving normal paraffin hydrocarbon would be significantly greater than that of sodium acetate for a given TOC level. However, attempts to induce a propagating organicnitrate/nitrite reaction with volatile organics (e.g., process solvents) proved negative in earlier investigations. When heated slowly and uniformly, volatile hydrocarbon was observed to evaporate (unreacted) before ignition temperatures were reached

(Baca et. al. 1978). To the extent that process solvents and their degradation products are present in single-shell tank waste, use of sodium acetate as an organic waste surrogate might be nonconservative. However, based on the current state of knowledge, a definitive assessment of the degree of non-conservatism (if any) is not possible.

- Organic chemicals disposed in the single-shell tanks, particularly the complexants addressed in Appendix $B$, are bel leved to have undergone significant aging (degradation) over the course of time, resulting in more highly oxidized (and therefore less energetic) waste forms (Babad et. al. 1993b). To the extent that waste aging has taken place in single-shell tank waste, use of sodium acetate as an organic waste surrogate is conservative. Again, however, a definitive assessment of the degree of conservatism is not possible basod on the current state of knowledge. In any event, it should be noted that the criteria in this document are not intended to apply to single-shell tanks known to hold, or known to have formerly held, a floating layer of organic (refer to Section 2.0). Criteria that address potential uncontrolled reactions between air and a floating organic layer, or air and solid waste saturated with organic liquid, will be developed as the Waste Tank Organic Safety Program matures.

- Recent work by John Watkin of Los Alamos National Laboratory has reported the presence of very small amounts of mononitro aliphatic carboxylic acids, and long chain aliphatic carboxylic acids resulting from contact of normal paraffin hydrocarbon/tributyl phosphate mixtures with strong nitric acid (at concentrations higher than those used in the Purex flow sheet) (Watkin 1993). Such species are likely to be somewhat more reactive with nitrate-nitrite oxidizer systems than the parent cumpounds. However, their low concentration under the highly reactive conditions used by Watk in suggests that they should not significantly enhance the fuel value of organic materials in the single-shell tanks. The Waste Tank Organic Safety Program plans to evaluate the characteristics (energetics and degradation) of these materials during FY 1994. 
In summary, use of sodium acetate as a representative organic waste surrogate appears to be reasonable based on the current state of knowledge. Additional single-shell tank waste characterization information, which addresses specific organic constituents rather than TOC content, is required to confirm this contention. This waste characterization information is scheduled to be obtained during FY 1994 and outyears.

\subsection{LEVEL I CRITERIA}

The technical basis for the Level 1 Criteria is a series of organic waste surrogate energetics tests conducted by Fauske \& Assoctates, Inc.

(Fauske 1993) and the United States Bureau of Mines (USBM 1993).

Fauske and Associates, Inc. used a Reactive Systems Screening Tool (RSST) adiabatic calorimeter to assess the conditions under which a mixture of sodium acetate-nitrate/nitrite salts could sustain a propagating reaction. The test mixtures employed are shown in Table 5-2.

The test mixture with 7 wt.\% TOC (Test 1, Table 5-2) exhibited propagating behavior at about $300{ }^{\circ} \mathrm{C}$ (Fauske 1993). However, the test mixture with 5 wt.\% TOC (Test 2, Table 5-2) showed exothermic behavior close to $200{ }^{\circ} \mathrm{C}$, but no transition to a propagating reaction (Fauske 1993). Results for the test mixture with 3 wt.\% TOC (Test 3, Table 5-2) were similar to those for 5 wt.\% TOC. From these data Fauske and Associates, Inc. conclude that a propagating sodium acetate-nitrate/nitrite reaction is possible at about 6 wt.\% TOC, but not for TOC concentrations below this value (Fauske 1993). Accordingly, 5 wt.\% TOC is selected as a reasonable upper limit for nonpropagating sodium acetate-nitrate/nitrite mixtures. Further, since sodium acetate is proposed to be a representative organic waste surrogate (refer to Section 5.1), 5 wt.\% TOC is recommended as a reasonable upper ilimit for single-shell tank waste classified as "safe."

Table 5-2. Test Mixtures for Fauske \& Associates, Inc. RSST Adiabatic Calorimeter Tests.

\begin{tabular}{|c|c|c|c|c|}
\hline Test & $\begin{array}{c}\text { Wt.\% TOC } \\
\text { (Dry Basis) }\end{array}$ & $\begin{array}{c}\text { Wt.\% Sodium } \\
\text { Acetate }\end{array}$ & $\begin{array}{c}\text { Wt.\% Sodium } \\
\text { Hydroxide }\end{array}$ & $\begin{array}{c}\text { Wt.\% Sodium } \\
\text { Nitrate/Sodium } \\
\text { Nitrite }\end{array}$ \\
\hline 1 & 7 & 24.0 & 12.0 & 64.0 \\
\hline 2 & 5 & 17.2 & 8.5 & 74.3 \\
\hline 3 & 3 & 10.4 & 5.0 & 84.6 \\
\hline
\end{tabular}

'One mole sodium hydroxide per mole sodium acetate.

${ }^{2}$ Sodium nitrate/sodium nitrite $-4 / 1$ weight basis.

Exothermic (but not propagating) behavior was noted for all three test mixtures included in Table 5-2, at temperatures above approximately $180^{\circ} \mathrm{C}$ (Fauske 1993). Gas pressures recorded in the RSST, as a result of exothermic behavior, are summarized in Table 5-3. Significant gas pressures (after cooldown) are evident. While RSST test results are not directly applicable to 
single-shell waste tanks, it is apparent that gas pressures generated by an exothermic organic-nitrate/nitrite reaction could concelvably compromise tank structural integrity. Therefore, criteria for single-shell tank waste classifled as "safe" must address the potential for exothermic (as well as propagating organic-nitrate/nitrite) reactions. A maximum waste temperature critert in of $149^{\circ} \mathrm{C}$ is recommended accordingly (refer to Table $4-1$, Section 4.0). This temperature is $22^{\circ} \mathrm{C}$ below the lowest exothermic reaction initiation temperature noted in organic waste surrogate energetics testing by Fauske \& Associates, Inc. (Fauske 1993) and the U. S. Bureau of Mines (USBM 1993), and is compatible with operating specifications for single-shell waste storage tanks (Boyles 1992). Maintaining single-shell tank waste temperatures below $149^{\circ} \mathrm{C}$ will ensure that significant gas pressures resulting from exothermic reactions are not generated.

Information from differential scanning calorimeter (DSC) tests conducted by the U. S. Bureau of Mines (USBM 1993) al so confirms the need for specifying a maximum waste temperature for single-shell tank waste classified as "safe." DSC tests were conducted using the sodium salt of ethylenediaminetetraacetic acid (EDTA) in flowing air and nitrogen, without oxidizer (sodium nitrate or sodium nitrate/sodium nitrite). Test results are shown in Table 5-4. These results show that, in air, EDTA decomposes and releases carbon dioxide and/or carbon monoxide from the four acetic acid groups. The ethylenediamine portion $\left(-\mathrm{NCH}_{2} \mathrm{CH}_{2} \mathrm{~N}-\right)$ is more stable, but if heated further, EDTA decomposes and forms a carbonate. Conversion to carbonate is complete at about $750^{\circ} \mathrm{C}$. The released carbon monoxide and the decomposition products oxidize in the flowing air and give rise to the large exotherm. The total amount of energy released during the exothermic process in three separate tests was approximately 7,870 Joules per gram $(\mathrm{J} / \mathrm{g})$ of EDTA. Tests in a nitrogen flow resulted in an exotherm which extends from roughly $185^{\circ}$ to $405^{\circ} \mathrm{C}$. The energy reledse for the main exotherm, found in two tests in nitrogen, was $545 \mathrm{~J} / \mathrm{g}$. The residues from the tests in nitrogen were black, as a result of pyrolysis without oxidation, whereas the residues from the tests in air varied in color.

Table 5-3. RSST Gas Pressures After Cooldown.

\begin{tabular}{|c|c|c|c|c|}
\hline \multirow{2}{*}{ Test } & \multirow{2}{*}{$\begin{array}{c}\text { Wt.\% TOC } \\
\text { (Dry Basis) }\end{array}$} & \multicolumn{2}{|c|}{ Moles of Gas Produced } & \multirow{2}{*}{$\begin{array}{c}\text { Gas Pressure } \\
\text { After Cooldown } \\
\text { (psi) }\end{array}$} \\
\hline & & Theoretical' & Actual & \\
\hline 1 & 7 & .043 & .044 & 44 \\
\hline 2 & 5 & .03 & .008 & 8 \\
\hline 3 & 3 & .019 & .003 & 3 \\
\hline
\end{tabular}

For reaction: $\mathrm{NaC}_{2} \mathrm{H}_{3} \mathrm{O}+1.6 \mathrm{NaNO}_{3} \rightarrow 1.3 \mathrm{Na}_{2} \mathrm{CO}_{3}+1.5 \mathrm{H}_{2} \mathrm{O}+0.7 \mathrm{CO}_{2}+0.8 \mathrm{~N}_{2}$. ${ }^{2}$ From reaction temperature to approximately room temperature. 
Table 5-4. DSC Results for Sodium Salt of Ethylenediaminetetraacetic Acid (Without Oxidizer) in Flowing Air and Nitrogen.

\begin{tabular}{|l|c|c|c|}
\hline \multicolumn{1}{|c|}{ Atmosphere } & $\begin{array}{c}\text { Decomposition } \\
\text { Onset Temperature } \\
(\circ \mathrm{C})\end{array}$ & $\begin{array}{c}\text { Peak Temperature } \\
\left({ }^{\circ} \mathrm{C}\right)\end{array}$ & $\begin{array}{c}\text { Decomposition } \\
\text { Exotherm }(\mathrm{J} / \mathrm{g})\end{array}$ \\
\hline Flowing air & $290-300$ & $400-410$ & $7,870^{2}$ \\
\hline Flowing nitrogen & $\sim 185^{1}$ & 370 & $545^{3}$ \\
\hline
\end{tabular}

${ }^{1}$ Difficult to determine.

${ }^{2}$ Average of three tests.

${ }^{3}$ Average of two tests.

In summary, the U. S. Bureau of Mines data confirms that at high temperature, organics (such as EDTA) can decompose in the presence of air with a large release of energy. A maximum waste temperature for single-shell tank waste classified as "safe" needs to be specified accordingly. Table 4-1, Section 4.0 , therefore includes a maximum waste temperature of less than $149{ }^{\circ} \mathrm{C}$ as a Level 1 Criterion.

\subsection{LEVEL 2 CRITERIA}

Level 2 Criteria, applicable in single-shell tank waste classified as "conditionally safe," permit TOC concentrations above the 5 wt.\% TOC (dry basis) specified by Level 1 Criteria. This is possible due to the inclusion of a minimum waste moisture criterion ( $\geq 17 \mathrm{wt} . \%$ ), and inclusion of a highly conservative maximum waste temperature $\left(\leq 90^{\circ} \mathrm{C}\right)$.

Adiabatic calorimetry test results by Fauske \& Associates, Inc., using the vent sizing package (VSP) calorimeter indicate that the heat of reaction for a sodium acetate-nitrate/nitrite mixture is approximately 3.7 mega Joules per kilogram (MJ/kg) of sodium acetate (Fauske 1993). The VSP adiabatic calorimeter measures adiabatic temperature rise to accurately determine the heat of reaction associated with exothermic activity. Using the $3.7 \mathrm{MJ} / \mathrm{kg}$ heat of reaction, and accounting for the sensible heat of reactants and the latent heat of vaporization of water, it is possible to estimate the weight fraction of water that would prevent a propagating sodium acetatenitrate/nitrite reaction with the following equations (Fauske 1993):

$$
\begin{gathered}
\mathrm{X}_{\mathrm{H}_{2} \mathrm{O}}>\frac{\mathrm{N}}{1+\mathrm{N}} \\
\mathrm{N}=\frac{\left(x-x_{n}\right) \Delta H_{R}-C_{M}\left(T_{O}-T_{i}\right)}{\lambda+C_{H_{2}}\left(T_{B}-T_{i}\right)}
\end{gathered}
$$


where:

$$
\begin{aligned}
& x \\
& x_{n} \\
& \Delta H_{R}(\mathrm{~J} / \mathrm{kg}) \\
& C_{M}\left(\mathrm{~J} \mathrm{~kg}^{-1} \mathrm{~K}^{-1}\right) \\
& T_{0}(K) \\
& T_{i}(K) \\
& \lambda\left(\mathrm{J} \mathrm{kg}{ }^{-1}\right) \\
& C_{H_{2} O}\left(\mathrm{~J} \mathrm{~kg}^{-1} \mathrm{~K}^{-1}\right) \\
& =\text { Specific heat of water }\left(\sim 4300 \mathrm{~J} \mathrm{~kg}^{-1} \mathrm{~K}^{-1}\right) \text {, and } \\
& T_{B}(K) \\
& =\text { Boiling temperature of waste }(\sim 393 \mathrm{~K}) \text {. }
\end{aligned}
$$

All parameters required to calculate $x_{H_{2}}$, the weight fraction of water required to prevent a propagating reaction, are specified except for $x$, the weight fraction of sodium acetate in a dry mixture, for which $x_{\mathrm{H}_{2}} \mathrm{O}$ is to be calculated. A bounding value for $x$ is 0.38 (38 wt.\% sodium acetate), that of a stoichiometric mixture of sodium acetate and sodium nitrate (Fauske 1993). Sodium acetate at $38 \mathrm{wt} . \%$ is equivalent to $11 \mathrm{wt} . \%$ TOC.

Using these values, the following results are obtained:

$$
\begin{gathered}
N=\frac{(.38-.172)\left(3.7 \times 10^{6}\right)-(1000)(573-323)}{2.25 \times 10^{6}+(4300)(393-323)} \\
N=.204
\end{gathered}
$$

* 17.2 wt.\% sodium acetate, corresponding to 5 wt.\% TOC (dry basis), from Table 5-2. Although the 5 wt.\% TOC test mixture did not support a propagating reaction (refer to Section 5.2 ), this value is used in the calculations shown here to estimate a conservative value for minimum required waste moisture content. 


$$
x_{H_{2} \mathrm{O}}>\frac{N}{1+N}=\frac{.204}{1+.204}
$$

$$
x_{H_{2} O}>.169
$$

In summary, for an estimated heat of reaction $(-3.7 \mathrm{MJ} / \mathrm{kg}$ sodium acetate), and assuming a stoichiometric mixture of sodium acetate and sodium nitrate, a waste moisture content $\geq 17$ wt.\% will prevent a propagating reaction. This is the technical basis for this criterion.

The remaining criterion, maximum waste temperature $590^{\circ} \mathrm{C}$, is established at this conservative level for two reasons:

- It is far below the lowest exothermic reaction initiation temperature noted in organic waste surrogate energetics testing by Fauske \& Assoctates, Inc. (Fauske 1993) and by the U.S. Bureau of Mines (USBM 1993), which is $171{ }^{\circ} \mathrm{C}$.

- It is $10^{\circ} \mathrm{C}$ below the lowest possible boiling point of aqueous single-shell tank waste $\left(100{ }^{\circ} \mathrm{C}\right.$ ) and $30^{\circ} \mathrm{C}$ below the boiling point expected for aqueous waste saturated with sodium nitrate. A maximum waste temperature of $90{ }^{\circ} \mathrm{C}$ will help to limit water loss from single-shell tank waste solids.

\subsection{LEVEL 3 CRITERIA}

Single-shell tank waste that falls to meet the Level 2 Criteria (conditionally safe) will be classified as "unsafe" (by definition). 
WHC-EP-0681

This page intentionally left blank. 


\subsection{TECHNICAL CONSERVATISM}

The interim criteria presented in Section 4.0 are to be used to conduct a preliminary screening of the 149 single-shell waste tanks at the Hanford Site in order to identify candidates for the organic tanks Watch List. The purpose herein is to identify tanks that require enhanced levels of monitoring and controls to meet safe interim storage objectives. The criteria are not to be used, in their present state of development, for resolution of the organic tanks safety issue. Additional laboratory testing, waste characterization data, and technical analyses are required to support safety issue resolution in a satisfactory manner. Given this qualification regarding intended application, the interim criteria are belleved to be reasonably conservative for the following reasons.

\subsection{REPRESENTATIVE ORGANIC WASTE SURROGATE}

In Appendix $\mathrm{B}$, it is demonstrated that sodium acetate $\left(\mathrm{NaC}_{2} \mathrm{H}_{3} \mathrm{O}_{2}\right)$ is a representative organic waste surrogate for the organic chemicals known to have been added to the single-shell waste tanks in large quantities. The "weighted average" chemical formula calculated in Appendix $\mathrm{B}$ is " $\mathrm{Na} \cdot{ }_{84} \mathrm{C}_{2} \mathrm{H}_{2},{ }_{58} \mathrm{O}_{2} .08 \mathrm{~N}_{18}$." This is then rounded to the nearest integer to yield " $\mathrm{NaC}_{2} \mathrm{H}_{3} \mathrm{O}_{2}{ }^{2}$ "The hiydrogen to carbon ratio from these two chemical formulas is shown in Table $6-1$.

Table 6-1. Carbon to Hydrogen Ratio.

\begin{tabular}{|l|c|c|}
\hline \multicolumn{1}{|c|}{ Calculation Step } & Chemical Formula & Hydrogen to Carbon Ratio \\
\hline "Weighted average" & $\mathrm{Na}_{.84} \mathrm{C}_{2} \mathrm{H}_{2.58} \mathrm{O}_{2.08} \mathrm{~N} .18$ & 1.29 \\
\hline "Rounded to nearest integer" & $\mathrm{NaC}_{2} \mathrm{H}_{3} \mathrm{O}_{2}$ & 1.50 \\
\hline
\end{tabular}

Use of sodium acetate (hydrogen to carbon ration $=1.50$ ) as a surrogate for the waste originally present in the tanks (hydrogen to carbon ratio $=1.29)$ is, in itself, a significant conservatism from an energetics standpoint. The energetics of an organic nitrate/nitrite reaction are expected to increase with hydrogen to carbon ratio (Babad et. al. 1993a). Hydrocarbon-like chemicals (chemical formula $\left[\mathrm{CH}_{2}\right]_{x}$ ) present a limiting case where the hydrogen to carbon ratio is approximately 2.0 .

The conservatism noted above is enhanced by waste aging (degradation) over the course of time as waste species originally present in the tanks are converted to more highly oxidized (and therefore less energetic) waste forms (Babad et. el. 1993b).

However, as discussed in Section 5.0, these conservatisms are offset (to an unknown but probably small extent) by the possible presence of process solvents and mononitro aliphatic carboxylic acid salts in the waste. 


\subsection{WASTE TEMPERATURE}

Section 5.2 discusses the technical basis for the $149{ }^{\circ} \mathrm{C}$ maximum waste temperature specified in the Level 1 Criteria. This temperature criterion is belleved to be reasonably conservative for the following reasons.

- The $149{ }^{\circ} \mathrm{C}$ temperature criterton is $22{ }^{\circ} \mathrm{C}$ below the lowest exothermic reaction initiation temperature noted in organic waste surrogate energetics testing by Fauske \& Associates, Inc. (Fauske 1993) and the U.S. Bureau of Mines (USBM 1993).

- The $149{ }^{\circ} \mathrm{C}$ temperature criterion is compatible with operating specifications for single-shell waste storage tanks. Operating specifications for single-shell tanks (Boyles 1992) require that waste temperatures not exceed $300^{\circ} \mathrm{F}$, which is equivalent to $149{ }^{\circ} \mathrm{C}$.

Section 5.3 discusses the technical basis for the $90{ }^{\circ} \mathrm{C}$ maximum waste temperature specified in the Level 2 criteria. This temperature criterion is belleved to be very conservative for the following reasons.

- The $90{ }^{\circ} \mathrm{C}$ temperature criterion is $81{ }^{\circ} \mathrm{C}$ below the lowest exothermic reaction initiation temperature noted in organic waste surrogate energetics testing, as discussed in the preceding paragraph.

- The $90{ }^{\circ} \mathrm{C}$ temperature criterion is $59{ }^{\circ} \mathrm{C}$ lower than the $149^{\circ} \mathrm{C}$ temperature criterion specified in the Level 1 Criteria.

- The $90{ }^{\circ} \mathrm{C}$ temperature criterion is $30{ }^{\circ} \mathrm{C}$ below the boiling point expected for aqueous waste saturated with sodium nitrate. Table 6-3 indicates that sodium nitrate is the principal inorganic constituent in Hanford Site tank waste, and waste solutions are generally found to be saturated with sodium nitrate.

- The $90{ }^{\circ} \mathrm{C}$ temperature is $10^{\circ} \mathrm{C}$ below the lowest possible boiling point of aqueous single-shell tank waste (100 ${ }^{\circ} \mathrm{C}$ for water).

\subsection{WASTE ORGANIC CONCENTRATION}

Section 5.2 discusses the technical basis for the 5 wt.\% TOC criterion. The test mixture with 7 wt.\% TOC* exhibited propagating behavior at about $300^{\circ} \mathrm{C}$. The test mixture with 5 wt.\% TOC* showed exothermic behavior close to $200{ }^{\circ} \mathrm{C}$, but no transition to a propagating reaction (Fauske 1993).

Consequently, the safety objective stated in Appendix $A$ (that no propagating organic-nitrate/nitrite reaction be possible) fails at some TOC concentration above $5 \mathrm{wt} . \%$ TOC and below $7 \mathrm{wt} . \%$ TOC. The value of $5.0 \mathrm{wt} . \%$ TOC was conservatively selected as the basis for the criterion. A somewhat higher TOC content might exhibit non-propagating behavior, but this has not been verified experimentally. Nevertheless, 5 wt.\% TOC probably represents some small (but presently unquantified) degree of conservatism.

*Based on sodium acetate as the organic waste surrogate. 


\subsection{WASTE MOISTURE CONTENT}

The waste molsture content required to prevent a propagating sodium acetate-nitrace/nitrite reaction is calculated in Section 5.3. The calculation uses an estimated heat of reaction $(3.7 \mathrm{MJ} / \mathrm{kg}$ sodium acetate) and assumes a bounding value for sodium acetate concentration ( 38 wt.\%), that of a stoichiometric mixture of sodium acetate and sodium nitrate (Fauske 1993). The assumption of a stolchiometric mixture is highly conservative for the reasons outlined below.

A stolchiometric reaction of sodium acetate and sodium nitrate is represented by the reaction:

$$
\mathrm{NaC}_{2} \mathrm{H}_{3} \mathrm{O}_{2}+1.6 \mathrm{NaNO}_{3} \rightarrow 1.3 \mathrm{Na}_{2} \mathrm{CO}_{3}+1.5 \mathrm{H}_{2} \mathrm{O}+0.7 \mathrm{CO}_{2}+0.8 \mathrm{~N}_{2}
$$

Table 6-2 calculates stotchlometric reactant quantities on a weight basis.

Table 6-2. Stoichiometric Reactant Quantities.

\begin{tabular}{|l|c|c|c|c|}
\hline \multicolumn{1}{|c|}{ Reactant } & Moles & Molecular Weight & Grams & Wt. \% \\
\hline Sodium acetate & 1.0 & 82.04 & 82 & 38 \\
\hline Sodium nitrate & 1.6 & 85.01 & 136 & 62 \\
\hline Total & & & 218 & 100 \\
\hline
\end{tabular}

The waste moisture content required to prevent a propagating reaction will decrease as reactant quantities deviate from the stoichiometric proportions shown in Table 6-2. This is because, at other than stoichiometric proportions, either excess fuel (sodium acetate) or excess oxidizer (sodium nitrate) is present. The heat of reaction available is at a maximum for a stoichiometric mixture, and decreases as the proportion of reactants varies to either side of the $38: 62$ weight percent proportion.

Inorganic constituents in Hanford Site waste are summarized in Table 6-3. 
Table 6-3. Inorganic Constituents of Hanford Waste.'

\begin{tabular}{|l|c|c|}
\hline \multicolumn{1}{|c|}{ Constituent } & $\begin{array}{c}\text { Estimated Quant } 1 \text { ty }{ }^{2} \\
\text { (Tons) }\end{array}$ & Wt. \% \\
\hline $\mathrm{NaNO}_{3}$ & 150,000 & 77 \\
$\mathrm{NaNO}_{2}$ & 19,000 & 23 \\
\hline $\mathrm{Na}_{2} \mathrm{CO}_{3}$ & 3,900 & \\
$\mathrm{NaAlO}_{2}$ & 10,000 & \\
$\mathrm{NaOH}^{2}$ & 15,000 & \\
$\mathrm{Na}_{3} \mathrm{PO}_{4}$ & 16,000 & \\
$\mathrm{Cancrinite}$ & 2,700 & \\
$\mathrm{Al}(\mathrm{OH})_{3}$ & 2,300 & \\
$\mathrm{Fe}(\mathrm{OH})_{3}$ & 1,200 & 100 \\
\hline Total & 220,100 & \\
\hline
\end{tabular}

From RHO 1980 as reported by Martin 1985.

? Only those compounds are listed whose quantity exceeds 1,000 tons.

${ }^{3}$ Known silica additions are assumed to have reacted with aluminates and hydroxides to form cancrintte (assumed to be $2 \mathrm{NaAlSlO}_{4} \cdot 0.52 \mathrm{NaNO}_{3} \cdot 0.68 \mathrm{H}_{2} \mathrm{O}$ ).

If the inorganic composition of single-shell tank waste is represented (on average) by the values in Table 6-3, a stoichiometric mixture of sodium acetate and sodium nitrate (or sodium nitrate/nitrite) is highly unlikely. The presence of $23 \mathrm{wt} . \%$ inert diluents would significantly reduce the heat of reaction avallable, compared to the stolchiometric reaction discussed above. The waste moisture content required to prevent a propagating reaction would therefore be reduced, as is evident from the calculations shown in Section 5.3 .

An additional waste moisture content conservatism is related in the water of hydration associated with many organic compounds. The U.S. Bureau of Mines makes the following observation in the section of their report entitled "Sample Preparation:"

"Anhydrous salts of the tetrasodium EDTA and of the sodium citrate were not commercially avallable. Instead, tetrasodium EDTA dihydrate and sodium citrate dihydrate were used in the tests. The weights of the fuels in the mixtures of the hydrous salts were modified to allow for the presence of the water of hydration. In each of the mixtures containing these fuels the water of hydration was released at a lower temperature than the temperature at which decomposition began in the DSC tests."

The endotherms associated with loss of water of hydration (at low temperature) partially offset the exotherm resulting from an organic-nitrate/nitrite reaction (at high temperature) (Bechtold 1993). This, in effect, contributes to suppressing a propagating reaction in a manner similar to that of unbound water (waste moisture content). The water of hydration bound to organic chemicals in the single-shell tanks represents a degree of conservatism that is not quantified in Section 5.3. 
The heat of reaction used in Section 5.3 to determine the moisture content required to prevent a propagating sodium acetate-nitrate/nitrite reaction was not affected by water of hydration. This heat of reaction (3.7 MJ/kg sodium acetate) was estimated using reagent grade anhydrous sodium acetate. Sodium ocetate also extsts as a trihydrate.

Appendix $C$ is a preliminary attempt to place the single-shell tank waste molsture issue into perspective. The following question is addressed in Appendix C.

"What is the equillorium molsture content of single-shell tank waste, under actively ventilated storage conditions, where the waste is continuousiy exposed to ambient air representative of that at the Hanford Site?"

The answer to this question provides a very conservative, bounding condition for the single-shell tank waste moisture issue. The preliminary results shown in Apnendix $C$ suggest that the equilibrium molsture content is about $22 \mathrm{wt}$. percent. It is of interest to observe that this equilibrium moisture content is above the minimum molsture content of 17 wt. percent specified in Section 4.0 for the "conditionally safe" waste classification.

The waste tank organic safety program plans to support additional work in this area during FY 1994 and outyears. 
WHC-EP-0681.

This page intentionally left blank. 


\subsection{REFERENCES}

Allen, G. K., 1976, Estimated Inventory of Chemicals Added to Underground Waste Tanks, 1944 Through 1975, ARH-CD-6108, Atlantic Rlchfleld Hanford Company, Richland, Washington.

Babad, H., M. D. Crippen, D. A. Turner, and M. A. Gerber, 1993a, Resolving the Safety Issue for Radioactive Waste Tanks with High Organic Content, WHC-SA-1671-FP, Westinghouse Hanford Company, Richland, Washington.

Babad, H., D. M. Camatoni, M. A. Lllga, W. D. Samuels, and D. M. Strachan, 1993b. Tank Waste Chenistry - A Now Understanding of Waste Aging. WHC-SA-1694-FP. Westinghouse Hanford Company, Richland, Washington.

Baca, R. G., G. A. Bettel, D. F. Mercter, E. L. Moore, and F. R. Vollert, 1978, Status of Containment Integrity, Studies for Continued In-Tank Storage of Hanford Defense High-Level Waste, RHO-LO-52, Rockwell Hanford Operations, Richland, Washington.

Bechtold, D. B., 1993, Thermochemical Analysis of Nuclear Waste for Safaty Assessment, WHC-SA-1983-VA, Westinghouse Hanford Company, Richland, Washington.

Boyles, V. C., 1992, Unclassifled Operating Specifications for Single-Shell Waste Storage Tanks, OSD-T-151-00013, Westinghouse Hanford Company. Richland, Washington.

Christensen, R. F., 1993, "Ferrocyanide Safety Issue Resolution Planning," Letter 93-CAB-290, to President, Westinghouse Hanford Company, Department of Energy, Richland Operations Office, Richland, Washington.

Fauske, H., 1993, Adiabatic Colorimetry (RSST and VSP) Tests with Sodium Acetate, Fauske and Associates, Inc., Burr Ridge, 111 inols.

Fisher, 1990. The Kyshtym Explosion and Explosion Hazards with Nitrate-Nitrite Bearing Wastes with icetates and Other Organic Salts, WHC-SD-CP-LB-003, Westinghouse Hanford Company, Richland, Washington.

Gerber, M. A., L. L. Burger, D. A. Nelson, J. L. Ryan, and R. L. Zollars, 1992. Assessment of Concentration Mechanisms for Organic Wastes in Underground Storage Tanks at Hanford, PNL-8339, Pacif IC Northwest Laboratory, Richland, Washington.

Godfrey, 1992, Operating Specification for Watch List Tanks, OSD-T-151-00030, Westinghouse Hanford Company, Richland, Washington.

Jungfleish, F. M., 1984, Preliminary Estimates of the Waste in Hanford Tanks Through 1980, SD-WM-TI-057, Rockwell Hanford Operations, Richland, Washington.

Martin, E. C., 1985, Complexant Stability Investigation Task 2 - Organic Complexants, PNL-5453. Pacific Northwest Laboratory, Richland, Washington. 
Reep, 1. E., 1993, Status Report on Resolution of Waste Tank Safety Issues at the Hanford Site, WHC-EP-0600, Westinghouse Hanford Company, RIchland, Washington.

RHO, 1980, Technical Aspects of Long-Term Management Alternatives for High-Level Defense Waste at the Hanford Site, RHO-LD-141, Rockwell Hanford Operations, Richland, Washington.

Richardson, D. C., 1992, Potential Unreviewed Safoty Question from Slow Organic Burn in Single-Shell Tanks at Hanford, Letter 92066468R1, to R. E. Gerton, Westinghouse Hanford Company, Richland Washington.

USBM, 1993, Testing of Organic Waste Surrogate Materials in Support of the Hanford Organic Tank Program, U.S. Bureau of Mines, U.S. Department of the Interior, Pittsburgh, Pennsyivania.

Watkin, J., Los Alamos National Laboratory, 1993, Personal Communication to Harry Babad, Westinghouse Hanford Company.

WHC, 1993, Hanford site Tank Farm Facyllties Interim Safety Basis, WHC-SD-WM-ISB-001, Vol. 1, Rev. O, Westinghouse Hanford Company, Richl and, Washington. 
WHC-EP-0681

APPENOIX A

SAFETY OBJECTIVE

App A-1 


\section{WHC-EP-0681}

This page intentionally left blank.

App A-2 
WHC-EP-0681

\section{APPENDIX A}

\section{SAFETY OBJECTIVE}

The primary safety objective is to ensure that no chemical reaction of the organic-nitrate/nitrite waste be possible that could

1. Produce radiation doses or toxic exposure either on-site or off-site in excess of applicable limits, or

2. Damage the tank so as to compromise its ability to safely store high-level waste.

The primary objective will be met by imposing the more stringent secondary safety objective that no propagating exothermic reaction be possible, regardless of the severity of its consequences. A propagating reaction is one that can spread beyond a local point of ignition.

The purpose of categorizing the organic-nitrate/nitrite waste hazard into safety levels is to help define single-shell waste tank monitoring and controls required to meet the safety objective stated above. The use of safety levels allows ranking of the tanks in terms of relative risk. At one extreme, where wastes are non-reactive, no monitoring or controls would be required to meet the safety objective. At the other extreme, reactive wastes (if any exist) would require mitigation and/or remediation in order to meet the safety objective.

Two key safety questions are posed to identify three safety levels.

\section{QUESTION 1}

Is a propagating exothermic reaction possible during interim storage?

The phrase "possible during interim storage" in Question 1 refers to conditions that could theoretically occur if no controls were placed on tank operations. This no control stipulation allows for possible but unlikely events such as waste dryout and the introduction of local reaction initiators. The no control stipulation does not, however, include operations that could be conducted during future efforts directed at waste retrieval.

If the answer to Question 1 is no, then the waste can be safely stored without human intervention. If the answer to question 1 is yes, then a second key question is posed as follows.

\section{QUESTION 2}

Is a propagating exothermic reaction possible under present conditions of waste moisture content?

If the answer to this question is no, then the safety objective can be met by imposing monitoring and controls that maintain moisture content above a level that prevents a propagatilig exothermic reaction. 
If the answer to this question is yes, then the safety objective can be met only by imposing controls that prevent the introduction of reaction initiators. The more stringent secondary safety objective cannot be met if the answer to Question 2 is yes.

Answers to these two key safety questions lead to the definition of three safety levels as follows.

\section{SAFE}

This safety level corresponds to a no answer to Key Safety Question 1: a propagating exothermic reaction is not possible during interim storage. The safety objective can be met by a hypothetical unattended operational mode. Monitoring and controls are not required for safe storage.

In terms of reaction phenomenology, the requirement is that any reaction be self-extinguishing, i.e., a reaction could not propagate at a measurable rate as the result of a localized reaction initiator. A second requirement is that radionuclide decay heat and heat generated by chemical reactions within a single-shell tank be passively dissipated without inducing a propagating exothermic reaction. Both of these requirements must be satisfied for a moisture level of zero.

\section{CONDITIONALLY SAFE}

This safety level corresponds to a yes answer to Key Safety Question 1 followed by a no answer to Key Safety Question 2. Single-shell tank waste in this category is safe on the condition that moisture level is maintained at or above a definable critical level.

In terms of reaction phenomenology, the requirements are the same as for the SAFE category with the exception that moisture level above a critical level applies. Therefore, a propagating exothermic reaction can be ruled out for this safety level.

\section{UNSAFE}

This safety level corresponds to yes answers to both Key Safety Questions. For single-shell tank waste in this category, a reaction initiated at a local point could propagate through a significant quantity of waste. Accidents would be prevented by imposing controls that prevent the introduction of reaction initiators. Waste in this category is subject to near-term mitigation and/or remediation actions.

Storage of wastes in this category is inconsistent with the more stringent secondary safety objective because a propagating exothermic reaction cannot be ruled out. A change in waste storage conditions, for example by adding water, would be required to assure that waste storage met the level of safety required by the safety objective. 
WHC-EP-0681

APPENDIX B

ORGANIC WASTE SURROGATE

App B-1 
WHC-EP-0681

This page intentionally left blank.

App B-2 


\section{APPENDIX 8}

Table B-1 calculates a "weighted average" chemical formula for an organic waste surrogate from information presented in Table 5-1.

As shown in the right hand column of the lower portion of the table, the "weighted average" chemical formula is $\mathrm{NaC}_{2} \mathrm{H}_{3} \mathrm{O}_{2}$, corresponding to sodium acetate.

Table B-1. Representative OrgantC Waste Surrogate.

\begin{tabular}{|c|c|c|c|}
\hline No. & Const i tuent & Formula (Table 5-1) & Gren Moles (Table 5-1) \\
\hline 1 & sodiun hydroxy acetate & $\mathrm{NaC}, \mathrm{H}, \mathrm{O}$ & $9.0 \times 10^{\circ}$ \\
\hline 2 & sodiun cltrate & $\mathrm{Na}, \mathrm{C}_{0} \mathrm{H}_{3} \mathrm{O}$ & $3.3 \times 10^{\circ}$ \\
\hline 3 & Sodiun salt of HEDTA & $\mathrm{Ne}, \mathrm{C}_{10} \mathrm{H}_{10} \mathrm{O}, \mathrm{N}_{2}$ & $2.7 \times 10^{6}$ \\
\hline 4 & Sodium selt of EDTA & $\mathrm{NO}_{1} \mathrm{C}_{10} \mathrm{H}_{12} \mathrm{O}_{0} \mathrm{~N}_{2}$ & $0.57 \times 10^{6}$ \\
\hline
\end{tabular}

\begin{tabular}{|c|c|c|c|c|c|c|c|c|}
\hline \multirow{2}{*}{ El ement } & \multicolumn{5}{|c|}{ Const ituent (Oram Moles $\times 10^{\circ}$ ) } & \multirow{2}{*}{$\begin{array}{l}\text { Normal lze to } \\
\text { Carbon }=1.00\end{array}$} & \multirow{2}{*}{ Multiply $\times 2$} & \multirow{2}{*}{$\begin{array}{l}\text { Round to } \\
\text { Nearest } \\
\text { Integer }\end{array}$} \\
\hline & From No. 1 & Erom No. 2 & From No. 3 & From No. 4 & Total & & & \\
\hline Na & $1 \times 9.0+$ & $3 \times 3.3+$ & $3 \times 2.7+$ & $4 \times .57=$ & 29.28 & .42 & .84 & 1 \\
\hline C & $2 \times 9.0+$ & $6 \times 3.3+$ & $10 \times 2.7+$ & $10 \times .57=$ & 70.50 & 1.00 & 2.00 & 2 \\
\hline H & $3 \times 9.0+$ & $5 \times 3.3+$ & $15 \times 2.7+$ & $12 \times .57=$ & 90.84 & 1.29 & 2.58 & 3 \\
\hline 0 & $3 \times 9.0+$ & $7 \times 3.3+$ & $7 \times 2.7+$ & $8 \times .57=$ & 73.56 & 1.04 & 2.08 & 2 \\
\hline$N$ & $0 \times 9.0+$ & $0 \times 3.3+$ & $2 \times 2.7+$ & $2 \times .57=$ & 6.54 & .09 & .18 & 0 \\
\hline
\end{tabular}


WHC-EP-0681

This page intentionally left blank.

App B-4 
WHC-EP-0681

APPENDIX C

\section{SCOPING EXPERIMENT TO DETERMINE MINIMUM MOISTURE \\ CONTENT IN HANFORD ORGANIC CONTAINING WASTE}

App C -1 
WHC-EP-0681

This page intentionally left blan!..

App C-2 


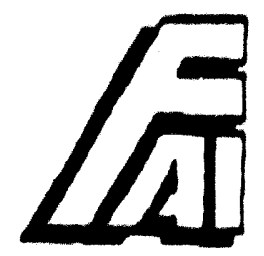

Favere s Acsealotes, ine.

Dat:: Sopeoaber 7, 1993

ID: Deve Turmar

Doy: Hane $K$. Fauske
Wasesnghouse Hanford Company

Fauke o Assoedates, Ine.

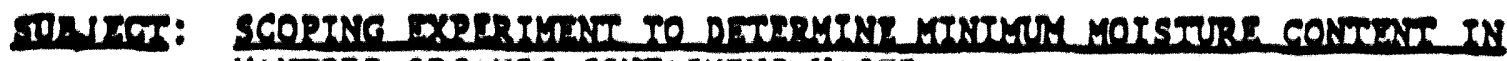

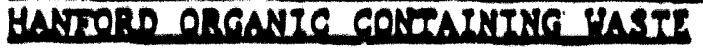

A long term drylng experlment do beling performed at FAI co decertmine the minlmu noleture content of sluulated Hanford organle concalning waseo. The scoplng experimene seartod out with a liquid solution consisting of:

\begin{tabular}{|c|c|c|c|c|}
\hline & & & (1) $y=x$ & HS DRY \\
\hline $\mathrm{NuNO}_{3}$ &.$\quad 16.4$ & $8 n$ & 24.6 & 34.4 \\
\hline $\mathrm{NaC}_{2} \mathrm{H}_{3} \mathrm{O}_{2}$ & 9.26 & 8 & 13.9 & 30.7 \\
\hline $\mathrm{NaOH}$ & $=\quad 4.49$ & $8 n$ & 6.8 & 14.9 \\
\hline $\mathrm{H}_{2} \mathrm{O}$ & . $\quad 36.42$ & 8 & 54.7 & - \\
\hline
\end{tabular}

The above solution (lnitlally no sallds prosent) was concalnod in an open $250 \mathrm{ml}$ Pyrax banker and exposed to ablone abr wheh a rolative humldicy of about sor (corrosponding to the yearly uverage value at the Hanford steo). since the solution was proparad on July 28, 1993, a ase loss of 27.93 pre has been masured as of Septomber 7. 1993. After 34 days, steady-scace appears so have been reached with no further volghe lose indlcared.

In the flese 25 days the mass loss was 27.12 an and durting ehis perlod the mazerial changed from an all-1lquid solution to a solid.llquid olxturo 
WHC-EP-0681

TO: Dave Turner

(sale cake and llake tormeton and solld proelpleaclon) and oventually te all dry-looklne eryscalline collds.

The subsequent capple valght loas bahavlor beyond 23 daye 1312. lustrated In Fif. I Indleating the approach to eteady-otate at about 34 days

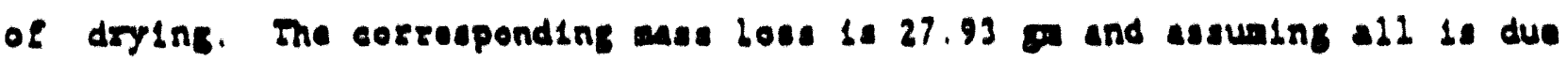

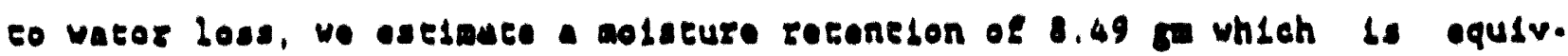
done to 22 Wh. IE ls of Intorose to note that chls value coapares voll wleh the driese $101.3 Y$ daes.

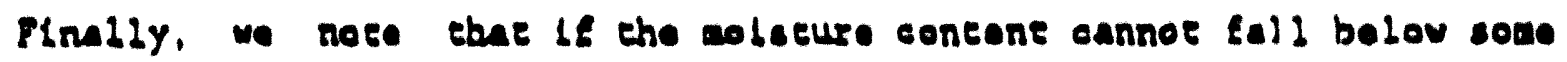
minlmum value (auch as 20 WO) due to Inherent natural phononona, the wase

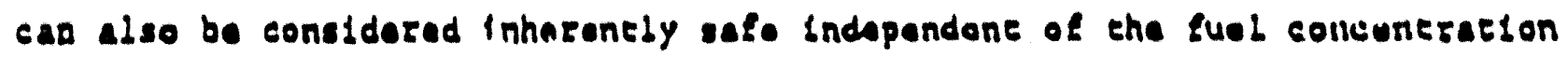
(san Rof. (1)). The alninum Dolature coneane abould tharefore play a kay role in escablishting the safocy erteorle for the vace canks. As such, we plall tu carty out a dedlcated RSST propagation geve using the resuletng residue fron the current drying experlaent. Based upon our current under. standing (see Raf. (LI), a dry mlxeure vith 9 Wh TOC should not exhlble propagating bohavior in the presence of aolsture concane of 22 Wo.

Any comencs you may have rolestng so tho above observaclons would be granely approclatod.

\section{Beference}

1. Fauske, H. K., "Adlabatle Calorlnatry (RSST and VSP) Toses with Sodtum Acetace", Meno to Deve Iumer dared Augute 17, 1993.

HOK : Lak

ce: R. J. Cash, WHC

D. Jeppson, WHC 


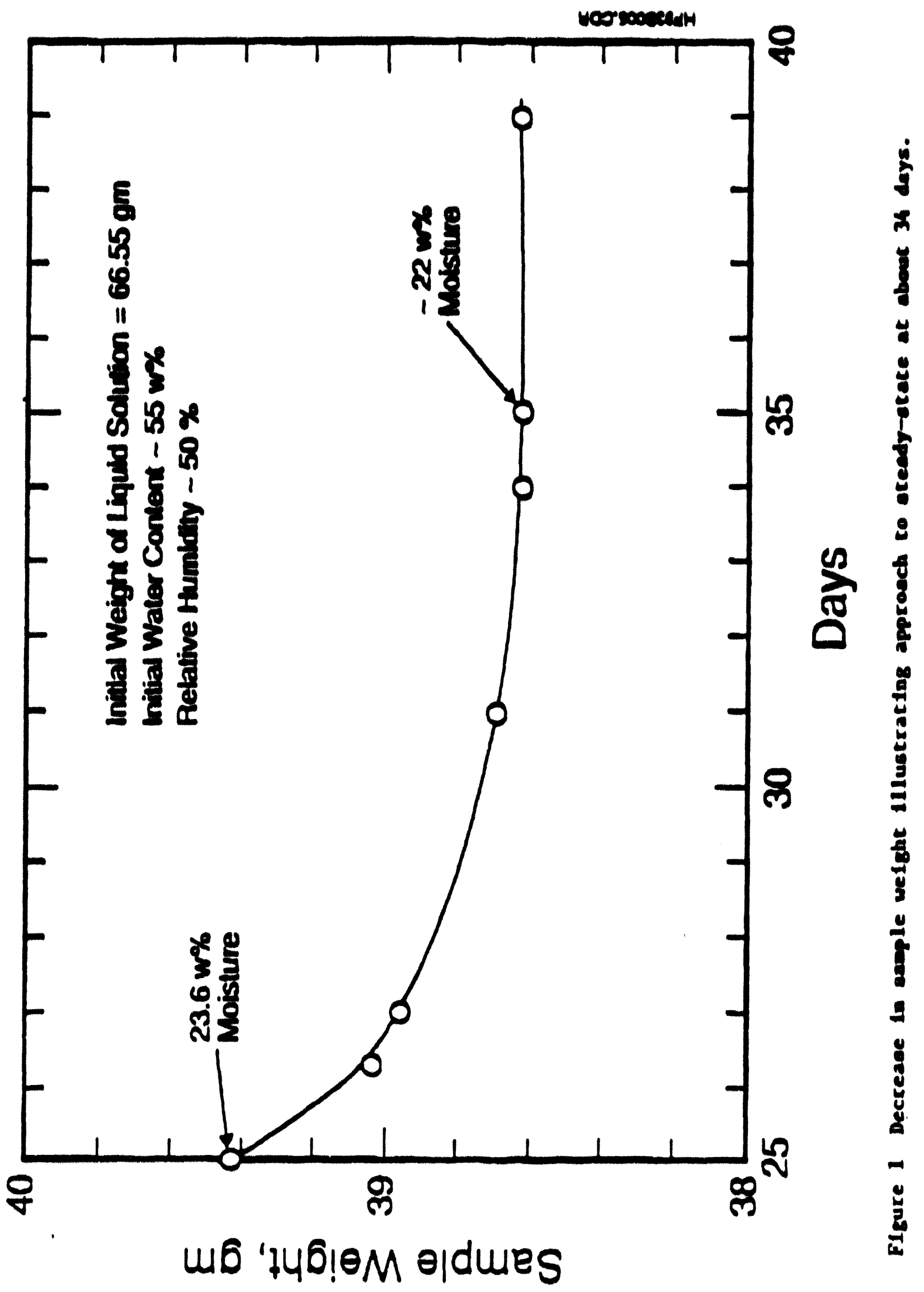

App C -5 
WHC-EP-0881

This page intentionally loft blank. 


\section{DISTRIBUTION}

Number of Copies

ONSLTE

\section{Mactec}

\section{Pacifta Northmest Leboratory}

8

R. M. Bean

D. M. Camatont

J. A. Campbeil

M. A. Gerber

B. M. Johnson, Jr.

R. D. Scheele

T. W. Wood

PNL Technical flles

P8.08

$\mathrm{K} 2-38$

P8.08

P8-38

KI-78

P7-25

$\mathrm{K} 8-41$

$k \mid-11$

9

U.S. Department of Eneray Bichland Fleld office

G. E. Bishop III

R3-72

G. J. Bracken

R3-72

R. F. Christensen (2)

R3-72

J. M. Clark

R3 -72

R. E. Gerton (2)

G. W. Rusenwald

Public Reading Room

R3 -72

R3-72

Al -65

West inghouse Hanford Company

W. T. Alumkal

R2-52

S. E. Ard

H. Babad

$R !-08$

R2-78

D. C. Board

S! -57

V. C. Boyles (2)

RI -49

R. J. Cash

R2-78

G. M. Christensen

$\mathrm{H} 4-21$

S. J. Dechter

C. Defigh-Price

R2-54

G. L. Dunford

R2-3!

D. B. Engelman

K. D. Fowler

G. T. Frater (2)

J. C. Fulton

K. A. Gasper

C. J. Geier

S. D. Godfrey

R!-5!

R2-18

R2-11

RI-5!

R2-31

R2-08

R2-50

R!-5] 
WHC-EP-0681

\section{Distribution (Continued)}

West inghouse Hanford Comoeny (Continued)

J. M. Grigsby

G. A. Hanson

H. D. Harmon

J. L. Huckaby

H4-62

$\mathrm{R2}-08$

$R 2-52$

R2-78

M. N. Isiam

J. R. Kasper

N. W. Kirch

J. M. Lentsch

R. M. Marusich

N. G. McDuffio

J. E. Meacham

A. F. Noonan

J. M. Osborne

H5. 53

R2-54

R2-11

R2-78

H4 -60

R2 - 78

R2-78

$\mathrm{R} 2-12$

$54-60$

M. A. Payne

R. S. Poplel arczyk

R2-50

A. K. Postma

R1 -30

P. R. Praetorius

H4-62

D. N. Price

J. G. Propson

T. E. Rainey

R. E. Raymond

I. E. Reep

W. E. Ross

J. P. Sederburg

L. E. Thomas

J. D. Thomson

D. A. Turner (25)

O. J. Wang

W. F. Zuroff

G] -63

$R 2-14$

R2- 18

$R !-49$

R2-54

R2-08

S5-07

R2-11

R3-08

RI -30

R2. -78

R2 -32

$R 2-14$

Document Processing and Distribution (2) Central files

$1.8-15$

1.8-04

Information Release Administration (3)

R!-08 

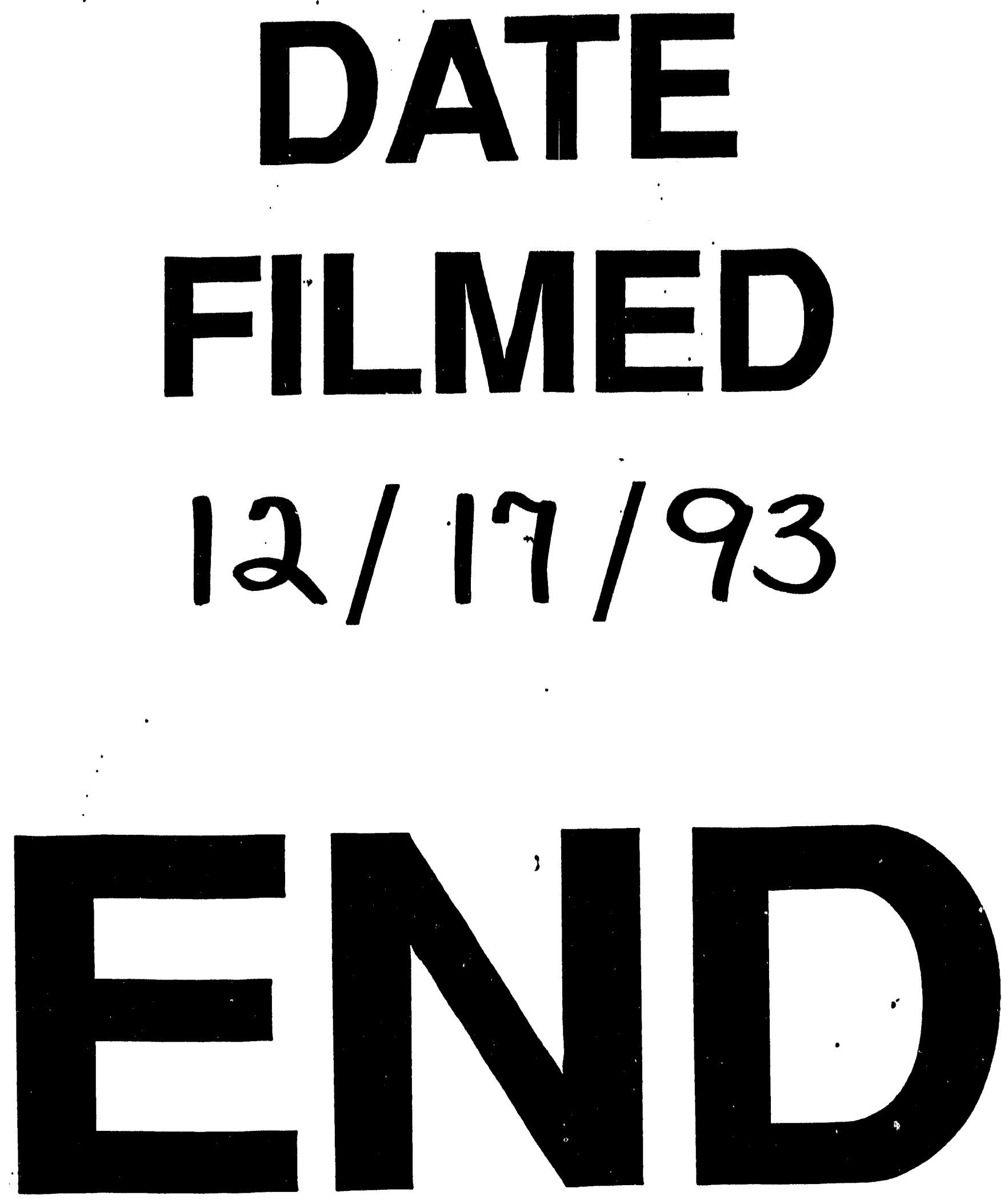


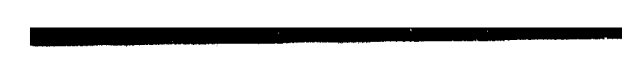

